\title{
Economic Growth: Shared Beliefs, Shared Disappointments?
}

\author{
Ricardo Hausmann \\ CID Working Paper No. 125 \\ June 2006
}

(C) Copyright 2006 Ricardo Hausmann and

the President and Fellows of Harvard College

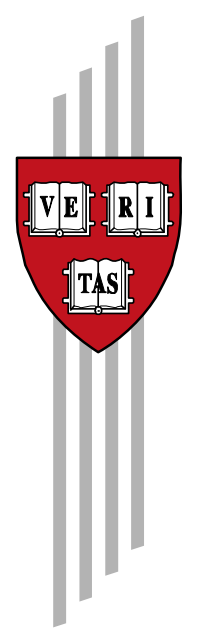

\section{Working Papers Center for International Development at Harvard University}




\title{
Economic Growth: Shared Beliefs, Shared Disappointments?
}

\author{
Ricardo Hausmann *
}

\begin{abstract}
There are two widely-held views on economic growth: 1) it is a natural outcome of getting 'the basics' right-- international integration, macroeconomic stability, and contract enforcement; and 2) it is hard, requiring a complete set of first, second, and third generation reforms that have little payoff until they are all implemented. Yet the evidence shows that growth accelerations do not naturally arise from the Washington Consensus basics, nor do they require extensive reform. Instead, accelerations are triggered by a more effective focus on identifying and removing the binding constraints to growth as they arise. This shifts the focus from creating a laundry list of reforms to using diagnostic signals to identify what particular constraints are holding back growth in a particular country at a particular time. Furthermore, growth involves not only coping with government failures, but also eliminating market failures. Therefore it is not just government sins of commission that drive down growth, it is also sins of omission: things that governments are not doing to overcome market failures. In many instances, there are ad hoc solutions that get the job done. Identifying and implementing such solutions requires a dynamic policy process where problems are identified and addressed, overcoming market failures while containing government failures.
\end{abstract}

Keywords: economic growth, growth diagnostics, Washington consensus

JEL codes: O10, O20

* Ricardo Hausmann is Director of the Center for International Development at Harvard University and Professor of the Practice of Economic Development at the Kennedy School of Government. This is his speech given at the G-20 Seminar on Economic Growth in Pretoria, South Africa, 4-5 August 2005. 


\title{
Economic Growth: Shared Beliefs, Shared Disappointments?
}

\author{
Ricardo Hausmann \\ Center for International Development and Kennedy School of Government \\ Harvard University
}

Let me thank all three central banks for the kind invitation to attend this meeting. I was here in South Africa a few months ago at the invitation of Minister Trevor Manuel and thanks to that I have been thinking a lot about this country. I have thought about Mexico for many years and am now also thinking about China with a group of academics that are preparing a study on that country, so I am thinking about the three countries that invited me and find it very appropriate that I have a chance to repay them with some ideas on such an important issue as economic growth.

\section{TWO VIEWS}

Let me try to create a simple framework for debate, so that I can present two views and then come up with a third one. The first view is that accelerating growth is easy. You have to get some fundamentals in place and then growth takes care of itself. An alternative view is that accelerating growth is highly complicated and requires a very long list of reforms; you must have first-generation reforms, second-generation reforms and third-generation reforms. Until you accomplish many of these reforms you should not expect much pay-off. So it is very hard to accelerate growth. Which of the two views is the right one?

When you have to deal with a controversial topic, a simple way of minimising risks is to quote your boss. In this respect, Larry Summers said:

I would suggest that the rate at which countries grow is substantially determined by three things: their ability to integrate with the global economy through trade and investment; their capacity to maintain sustainable government finances, [that is why the Minister of Finance is here], and sound money; [that is why the Central Bank is here], and their ability to put in place an institutional environment in which contracts can be enforced and property rights can be established. I would challenge anyone to identify a country that has done all three things and has not grown at a substantial rate.

Well, I don’t know, I can think of many: South Africa, Mexico, El Salvador, Morocco.

And I would challenge anyone to identify a country that for any significant period of time, has been held back either by excessive trade links with the global economy, overly sound public finances, or property rights and contracts that are excessively enforced.

So that means if you do these three things, you grow. Do not worry about overdosing on them. Do as much as you can and if you do enough you grow; that is more or less the message. 


\section{Implications of this view}

On the implications of this view, let me quote another well-known paper: ${ }^{1}$

Once a developing country government establishes the rules to a fair game and ensures their enforcement it would be well advised to stand back and enjoy the selfgenerating growth.

The message is clear: get your act together and then growth happens by itself. In other words:

- Open up to trade and investment

- Maintain decent fiscal and monetary policies

o Finance ministers: just focus on fiscal consolidation

o Central bank governors: focus on inflation and credibility

- Ensure the rule of law and contract enforcement

- Let things take their own course.

What is the deep logic behind this view?

We can discern the implicit logic behind this view.

- Opening to the global economy through trade liberalisation will create the markets for selling goods

- Openness to investment and finance will allow the country to get the ideas, the knowledge, the contacts and the savings to exploit that market

- Sound public finances and stable money will permit opportunities to be exploited without the fear of expropriation through inflation and default

- Property rights and contract enforcement imply that transaction costs will not tax away these new possibilities.

The implicit assumption in this view is that growth is the natural consequence of wellfunctioning markets, once government-induced distortions are removed. So it is governments that, because of their actions, prevent these markets from operating well and consequently prevent growth from taking place. Once you take out these governmentinduced distortions, growth happens. So you should ask yourselves: "What am I doing that is preventing growth?” (Trade restrictions, irresponsible fiscal policy, etc.) This is in contrast to asking yourself: "What am I not doing that might be good for growth?" It is about the sins of commission, not the sins of omission. It is about dismantling obstacles more than about constructing opportunities. For example, successful integration into the world economy is seen as the consequence of liberalisation, so the reason you have not integrated successfully is not because you are not doing some things that help you to integrate successfully but because you are preventing natural integration from taking place through protective trade policies. So the question is: "Does successful integration involve just liberalisation or does it involve something else?”

\footnotetext{
${ }^{1}$ Roll, R and Tallbott, J (2001) Why many developing countries just aren’t. Unpublished paper. November.
} 


\section{THE FASTEST-GROWING COUNTRIES IN 1978-2003}

Now, let us look at the growth experience over the previous 25 years. Figure 1 shows the rate of growth of the fastest-growing countries in the world in the 1978-2003 period. The first column is GDP per worker, the second column is GDP per capita, and the last column is total GDP. And you see, whichever way you measure it, the events in China are really remarkable: Chinese output per worker at 7.8 per cent annually is 2.8 percent faster than the second country. The gap between China and the second country is huge: the gap is much higher than the average growth in the world. The second country happens to be Botswana, right here in the neighbourhood, which is followed by Korea, Thailand, Ireland, Singapore, Hong Kong, India, Malaysia, Indonesia and Chile. So growth in the GDP per worker up to the tune of 3 per cent already gets you into the major leagues, 4 per cent is very unusual and 7 per cent is unique.

\section{Figure 1. The fastest-growing countries} (1978-2003)

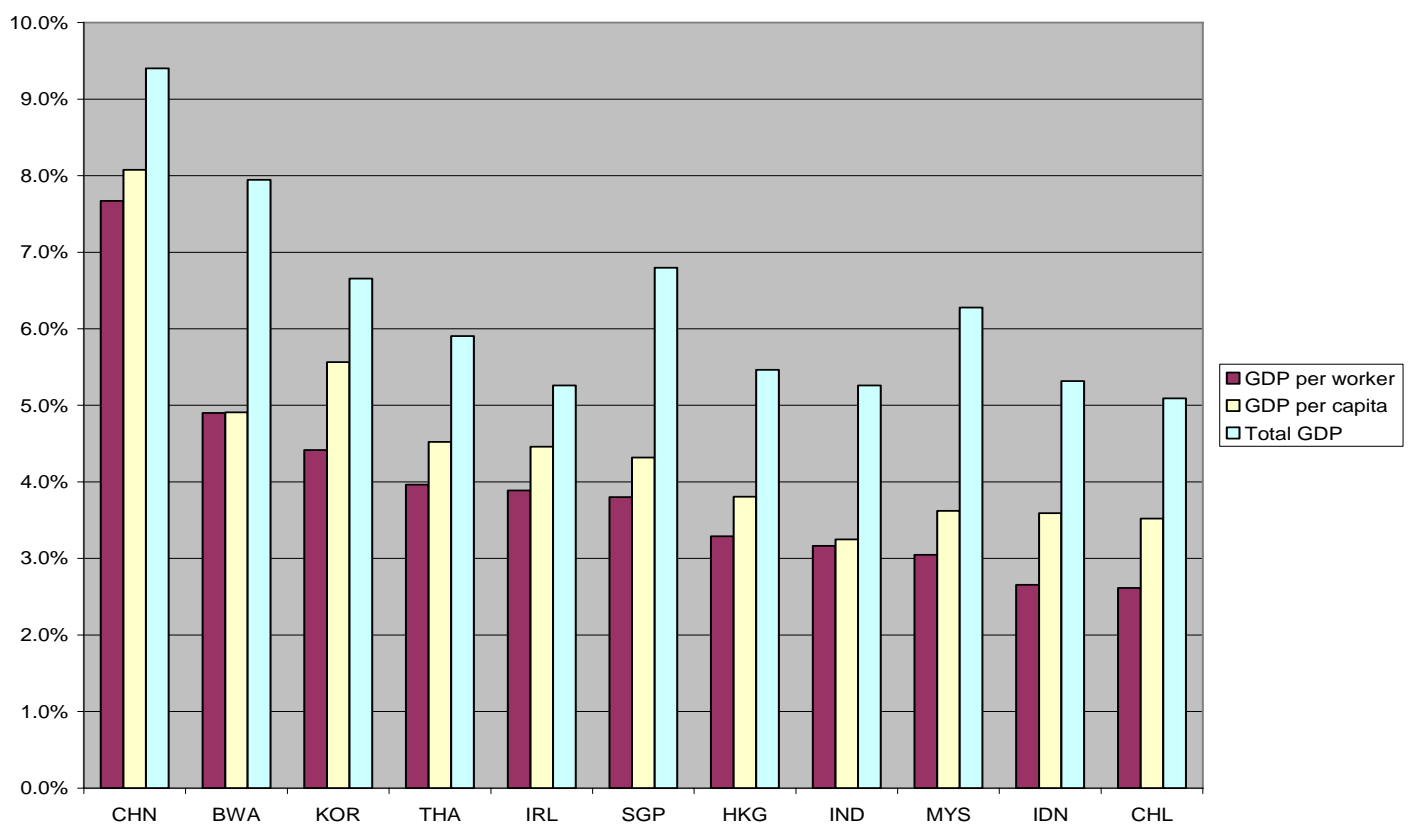

Successful integration is important in the sense that the countries that grow fast also have a very fast growth in exports. Figure 2 shows the relationship between export growth and growth in GDP per capita for the same period. The figure makes a powerful point: fastgrowing countries have been growing exports very quickly. China is again an outlier, exhibiting the fastest growth rates with a substantial lead in both dimensions. Interestingly, some not-very-fast-growing countries like Turkey and Mexico are very fast export growers. 
Figure 2. Growth in exports vs. growth in GDP per worker (1978-2003)

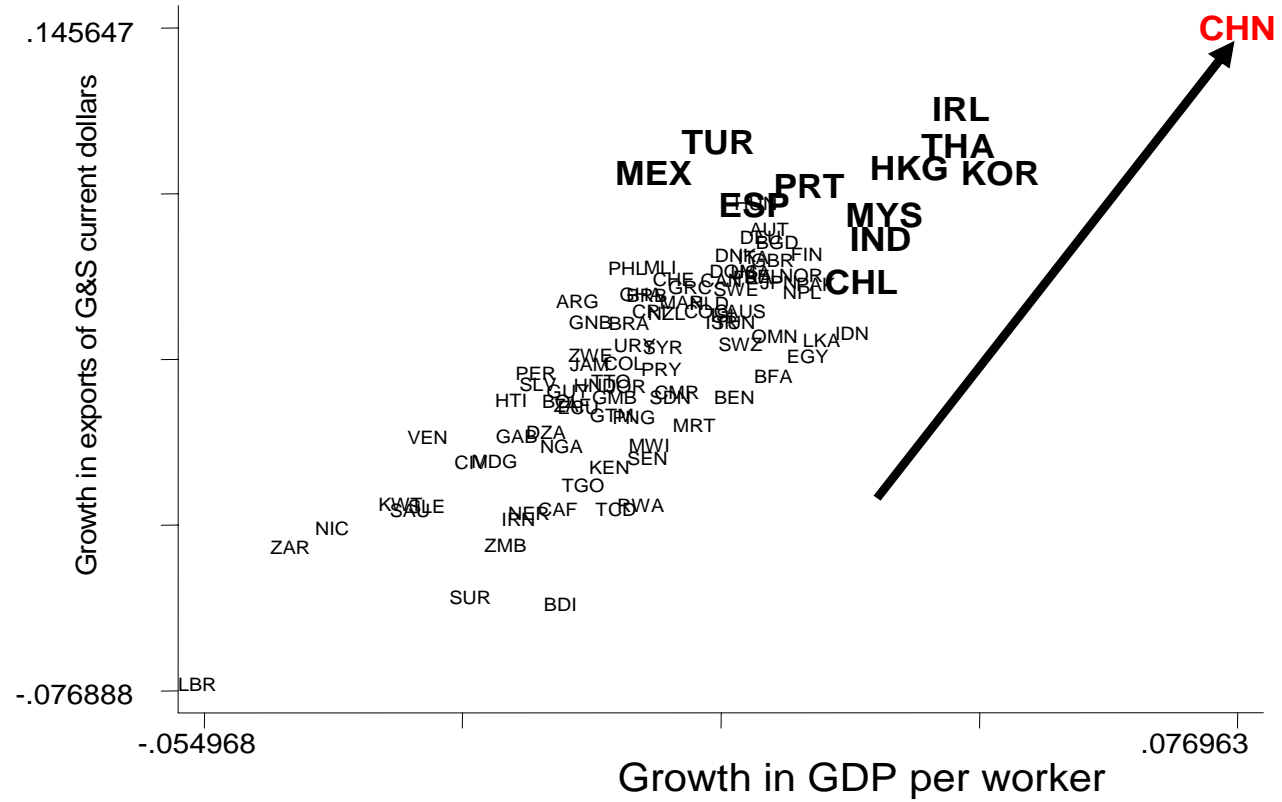

Now, in my part of the world - Latin America - the reform agenda summarised by Summers was broadly implemented. When I was at the Inter American Development Bank, we developed an index of the reform effort, which measures the percentage convergence to the best performer in the region in the areas of trade, finance, fiscal, privatisation and labour. Progress between 1985 and 1995 is depicted in Figure 3. The graph shows that much reform has taken place, especially in trade and finance.

Figure 3. Improvement in structural policies in Latin America

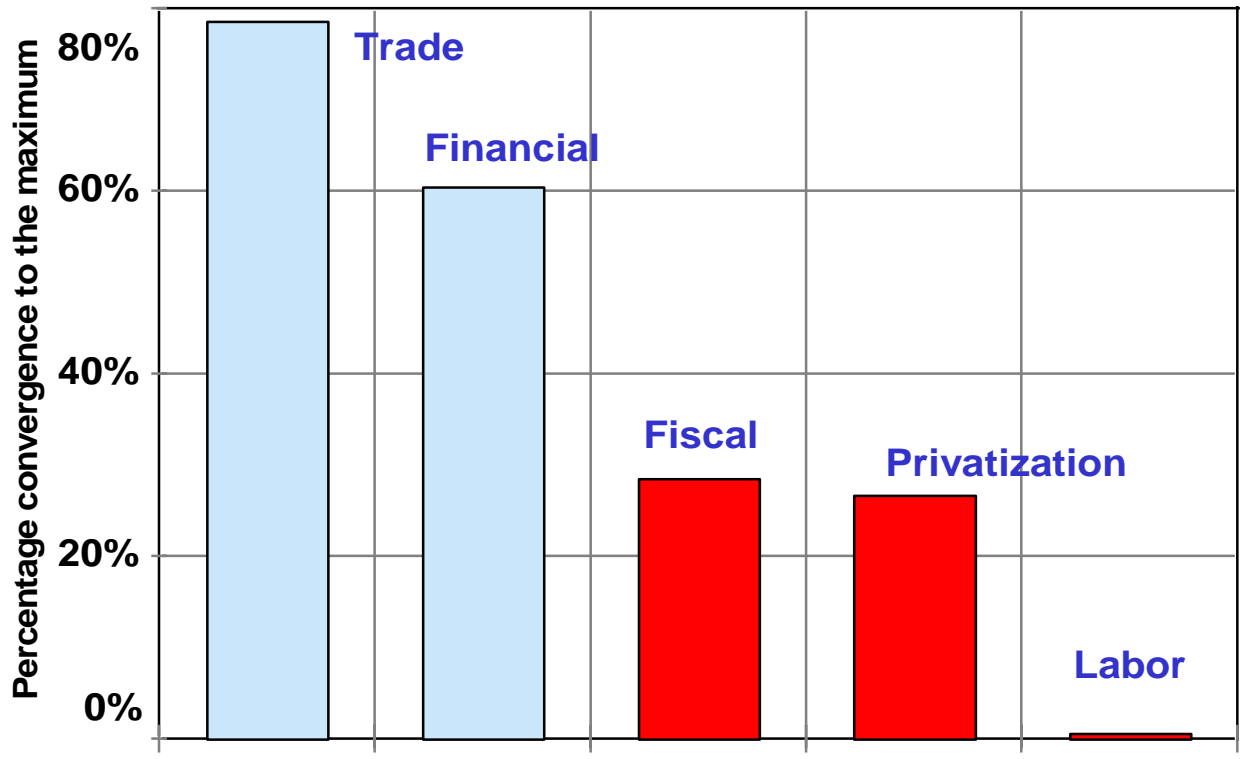


The leader in reform in our region is Chile, and countries have been converging towards Chilean policies. Interestingly, growth outcomes have not been converging towards Chilean rates, but have instead been diverging. Figure 4 measures GDP per worker relative to that of the US in the 1980-2002 period. By definition, the US is rated zero. And you see here that Chile has been converging towards the US. But everybody else has been diverging from the US and from Chile, even though their policies have been converging towards Chilean policies. I think this illustrates an important source of disappointment. If you were to take a standard model of growth and project what should have been the rates of growth considering the amount of reform that countries have made, you would have expected convergence, but that did not happen.

\section{Figure 4. Cumulative growth in GDP per working-age person, relative to the USA 1980-2002}

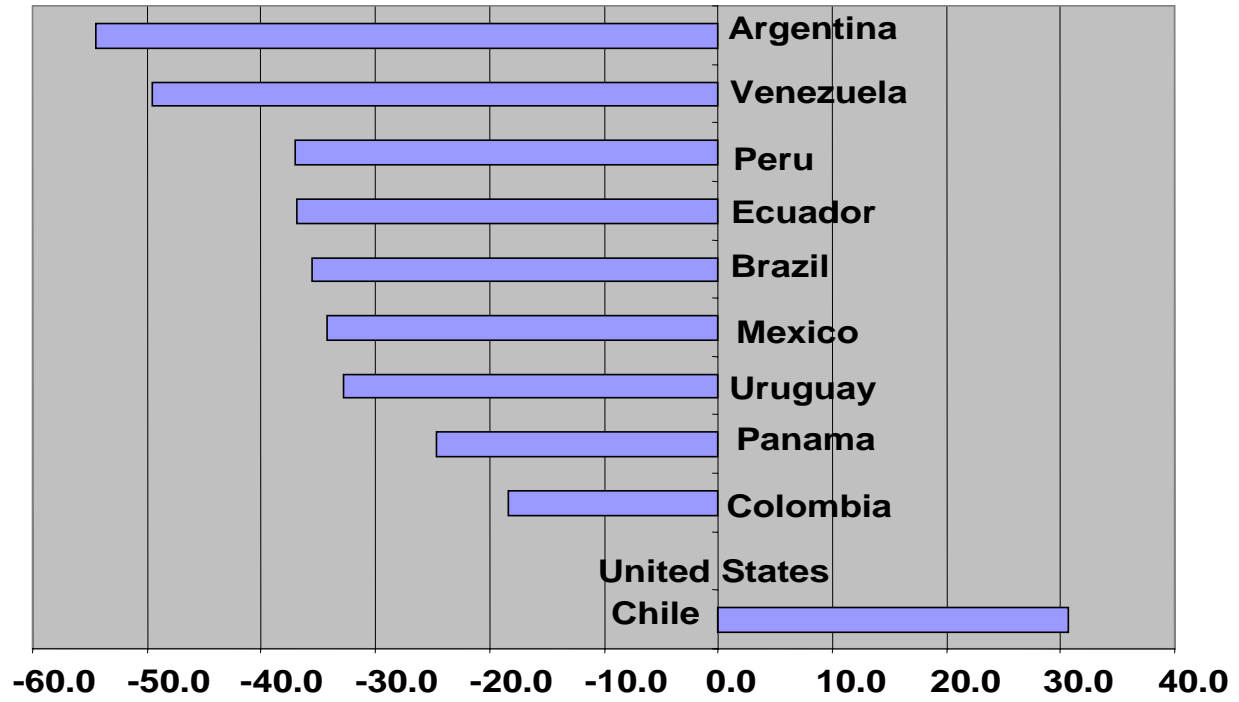

So there is something about this agenda that was tried, and might have worked in some countries but did not work as expected on average. There is political impatience with wellmeaning governments and it is hard for societies to distinguish between what is good about the reforms that they have made and what is not so good, hence facing the danger of throwing the baby out with the bath water.

One of the readings of this experience is that achieving growth is really hard. It is not enough to bring inflation from three digits to single digits, open up the economy to trade and investment, privatise state-owned enterprises and reform the financial system. There is really much more to be done. This alternative view is well captured in a speech by Anne Krueger in 2004, aptly titled: "Meant well, tried little, failed much.” The central point of this view is clear: we know what it takes, but you just have not done enough. In other words, accelerating growth is intellectually clear but may be hard to do in practice. The problem is lack of "political will”.

Clearly, an alternative interpretation of the same data would say that it is hard to secure political will if the reforms do not deliver the expected results. Blaming insufficient reform ex post facto is easy if you do not provide an ex ante measure of how much reform is 
actually necessary to get the growth process going. You can always argue that more was needed. There must be a more constructive discussion of this issue.

\section{A SYNTHETIC VIEW OF GROWTH STRATEGIES}

Let me present very quickly a very synthetic view on growth and on growth strategies. Think of income as being the outcome of three things: how many factors of production you have, how productive your use of those assets is, and how appropriable the income generated by your efforts is:

Private income $=$ appropriability $*$ productivity $*$ factors of production

So you can work on each of these three elements. In other words, you can

- accelerate factor accumulation: more factors of production;

- improve the appropriability of the returns;

- increase productivity.

Note that if you get a zero in any of these elements, it does not matter how many of the other factors you have. So these elements complement one another.

\section{Strategy one: Accelerate factor accumulation}

Now, if you want to accelerate factor accumulation, you may want to increase the availability of both domestic and foreign savings. To raise domestic savings you may pay attention to increasing public savings, improving financial systems or reforming social security. To raise foreign savings you may want to increase official international lending, stimulate foreign direct investment or open the capital account.

The factors of production involve not only physical capital but also human capital. So you may want to promote education by increasing the budgetary allocations to education, and improving the effectiveness of those allocations.

\section{Strategy two: Improve expected appropriability}

The second strategy would involve improving the expected appropriability of efforts. This can be achieved through the following lines of action. First, by adopting low and predictable taxes. Second, by reducing the probability of expropriation through macro crises by focusing on fiscal sustainability, financial soundness and external balance. Third, by improving the contractability of labour, capital foreign trade and investment. Fourth, by improving property rights and judicial enforcement. Fifth, by reducing corruption and crime. Sixth, by assuring political stability and governance, so that people can expect something about the rules of the game.

\section{Strategy three: Increase productivity}

Strategy three involves increasing productivity. Here there has tended to be a relatively restricted, orthodox or uncontroversial list of thing to do. These include the following to-do list: focus on education, but watch out for excesses on university spending because that tends to go to the rich; improve productivity through openness to foreign trade and investment, but watch out for subsidies; provide complementary public investments in infrastructure, but watch out for picking winners. In other words, do things that are good for 
a broad set of sectors, not for specific sectors; provide protection of intellectual property rights, so that people can invest in ideas with the expectation of benefiting from their value.

I view this list as rather restrictive and will talk about why below.

\section{What kind of reform advice do countries get?}

The typical message that countries have been getting is clear: do everything. This involves coming up with a long laundry list of necessary reforms, like the one implied by the three strategies mentioned above. There is typically little sense of priorities or optimal sequencing and the implied message from Larry Summers is that you cannot overdose on reforms while the message from Anne Krueger is not to expect too much until all reforms are in place.

There is an implied assumption in this agenda. It is that any reform is good at any time; the more areas reformed, the better and the deeper the reform in any area, the better.

The only problem with this approach is that economic theory provides no reason to think any of the above is true. And the reason is the so-called theorem of the second-best, which says that if you have an economy with several distortions, eliminating one of them is not necessarily welfare-enhancing. If you eliminate one distortion and you still have the rest of the distortions in place, you can make things better or worse.

\section{GROWTH ACCELERATIONS AND LIBERALISATION}

In a paper with my colleagues Dani Rodrik and Lant Pritchett, we tried to understand how it is that countries accelerate their growth rates. We define a growth acceleration as an instance when a country starts growing at least at 3.5 per cent per capita for a period of at least eight years, representing an acceleration of at least 2 percent from their previous experience. So we want to focus on the periods when countries suddenly start to grow faster.

We had the expectation of finding some 12 or 15 cases in the period for which we have data, which is from 1950 onwards for a few countries and from 1960 for more of them. Instead we found 83 cases, far more than we expected. This means that the typical country has a 25 percent chance per decade to experience a growth acceleration of this magnitude. This suggests that accelerating growth cannot be contingent on too many preconditions because it is too frequent a phenomenon. Interestingly, only 14.5 percent of major economic liberalisations are followed by growth accelerations. So the great majority of economic liberalisations are not. And only 18.2 percent of growth accelerations are preceded by major economic liberalisations. So the idea that if you adopt a significant economic liberalisation you are more or less assured of triggering growth, is not the common feature of the data.

However, the data also shows that not all growth accelerations are sustained. About 40 percent revert back to either slow or negative growth after the 8-year period.

The implication of the above is that it does not appear that growth accelerations require a long laundry list of reforms. They seem to happen with high frequency and not mainly in 
countries that have adopted major reforms. They seem to happen when the binding constraints on growth are removed, not all the constraints, but the distortions that seem to bind the most. As this happens, the economy starts growing, but then other things become binding. If these constraints are not removed, growth peters out. So, accelerating growth and sustaining high growth require very different approaches. If you have a country that is not growing much, the strategy to get it to grow fast should be to remove the most binding constraint. When the country is already growing fast, the challenge is to remove the future constraints as they become actually or potentially binding.

Hence, if countries face low growth, focus on the binding constraints. That would be the paradigm that emerges here. This is in essence an optimistic message. It says your task may be easier than you think.

\section{Growth diagnostics : Identifying the binding constraints}

In a paper with my colleagues Dani Rodrik and Andrés Velasco, we argue that identifying the binding restrictions to growth is also doable with economic analysis. Imagine the following stylised production function:

Output = F(physical capital, human capital, infrastructure, institutions, etc.)

Assume that output depends on how much physical and human capital you have, how much infrastructure, institutions, etc. Assume also that these factors are complements in production. We have good reasons to believe they are complements because rich countries have more of all of them than poor countries. Under these assumptions, the binding constraint to growth is going to have a very high marginal return, and interestingly, since factors are complements, it will drive down the return of other factors.

So, when I find a country that has, say, a low rate of savings, but I find that real interest rates in that country are low and the country has access to foreign sources of lending that it is not using, it cannot be the case that growth is being held back by a lack of savings, even if savings are low. If a country has low levels of education but the returns on schooling are low, it means that growth is not held back by lack of education. The idea is that if the shadow price of a constraint is low, the constraint cannot be very important. Something else must be constraining growth. So you can use this identification strategy to identify the binding constraints.

In the above-mentioned paper with my colleagues Dani Rodrik and Andres Velasco, we came up with a strategy to perform a diagnosis of the obstacles to growth. We start by asking the question: what is limiting private investment and entrepreneurship? Is it because finance is very expensive or is it because the returns to investment are low? And if it is low returns to economic activity, is it low social returns or is it low appropriability of those returns? At each stage you try to derive what signal or testable implication would lead you to believe that you are in that part of the decision tree. When you apply it to different countries, you end up with very different explanations of what is constraining growth and hence with very different priorities for policy reforms. 
Figure 5. Growth diagnostics

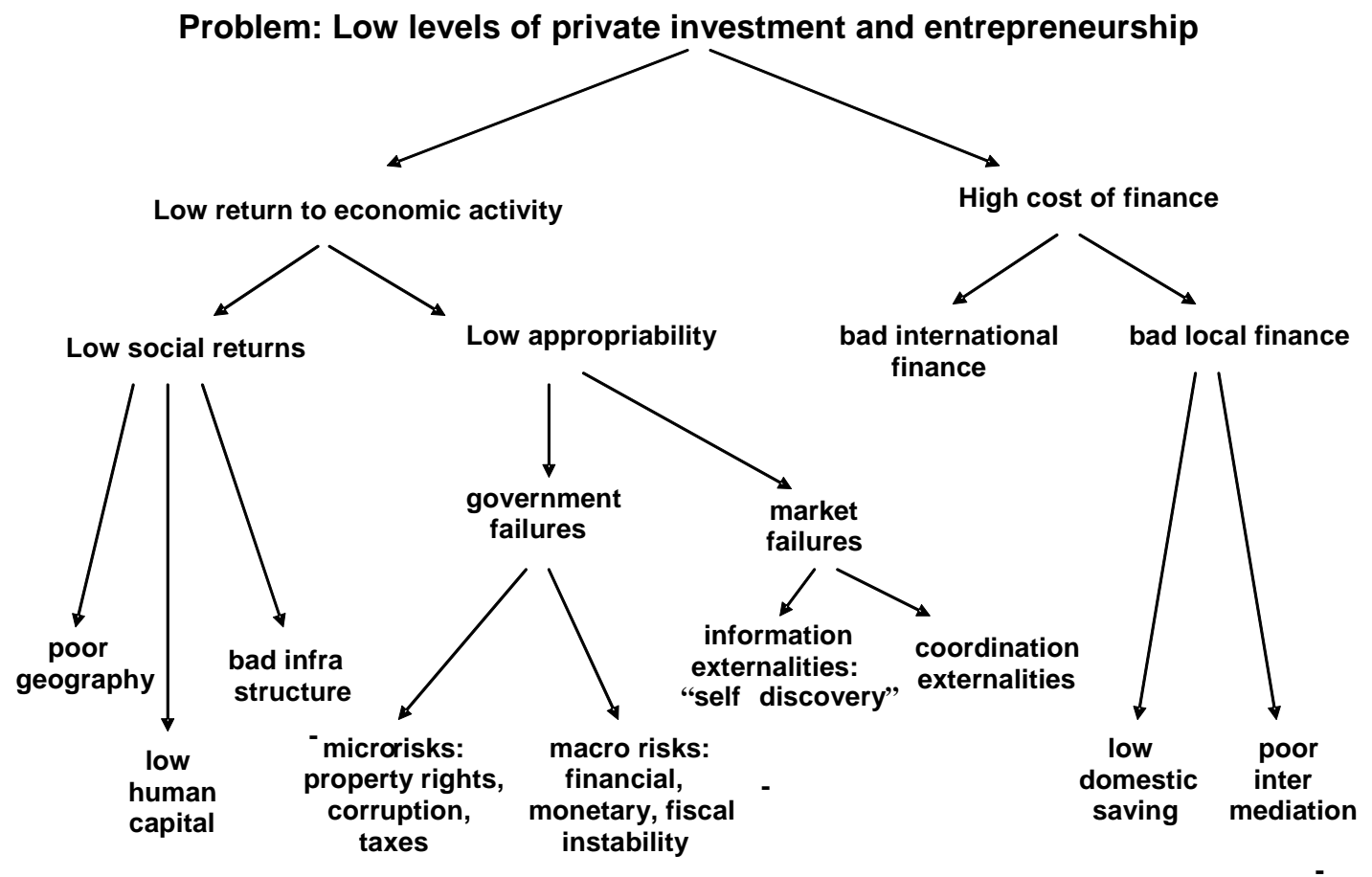

In Brazil and Turkey, for example, we would argue the problem is insufficient domestic savings due to large fiscal commitments. The country can grow if and when it has access to foreign savings, but when these are exhausted, the interest rate has to be high enough to discourage additional investment. The equilibrium happens at very high interest rates because that is what it takes to bring investment demand down to available savings. Savings are constrained by an overcommitted public sector (due to high debt or pension obligations) which requires high levels of taxation with negative levels of public savings.

In another country that we worked on, El Salvador, we find low returns to investment in spite of adequate human and institutional capital. Interest rates are very low but this does not trigger sufficient levels of investment. Hence, something else is keeping investment returns low. We instead argued that the problem in that country is lack of dynamic exportable activities, which the country needs to identify. So in El Salvador we would focus on a more active industrial policy while in Brazil we would privilege an increase in public savings.

\section{Fiscal consolidations and growth}

Now, let me go very quickly through some current work I am doing with my colleague Ugo Panizza. We ask ourselves whether fiscal consolidations are expansionary. This is a question that was studied earlier by Roberto Perotti for Europe, who found that consolidations are expansionary when they are achieved through expenditure cuts. If this is true in general, a finance minister can argue that by focusing on sustainability through fiscal consolidation, fiscal policy makes its most important contribution to growth just as 
central banks like to argue that by focusing on inflation, they make their most important contribution to growth.

We have some evidence that growth affects fiscal consolidations in the sense that a period of bad growth performance tends to predict a future fiscal consolidation. Empirically, this is mainly driven by the experience of Eastern Europe in the 1990s. We also find that countries that have growth collapses tend to have a worse fiscal performance afterwards. But we uncover no evidence for the idea that fiscal consolidation fosters sustained growth. In other words, we find no Perotti effect over the medium term.

Our interpretation is that fiscal consolidation may be good if you want to avoid crises and keep a sustainable position, but don't expect it to accelerate growth over the medium term, unless you face a situation where crowding out is important, as in Brazil or Turkey.

The broader point here is that macro policies are not a growth strategy. Macro policy is really about avoiding crises. It is about keeping the economy close to its potential, to its speed limit. But it is not about raising the speed limit.

Hence, a good macro policy does not constitute a growth strategy. I think good macro is an important task, but in itself it is not a growth strategy. But good growth makes good macro much easier. And this is very clearly borne by the facts. If you have good growth, taxes will be abundant and the finance minister will look good to everybody: he can increase spending and balance the budget at the same time. A good growth strategy will make macro policy much easier; if you don't have good growth then good macro performance becomes very hard to achieve.

More importantly, there may be difficult tradeoffs between a growth strategy and the traditional goals of macro policy. These are often overlooked by stressing instead the line: "do the macro and that's good enough for growth". It is important to be conscious of what the tradeoffs might be. For example, should fiscal policy focus on limiting debt accumulation or should it be focused on improving the public sector's net worth?

Let me discuss this issue in the context of a specific example: India, a country I visited recently. The fiscal deficit there was around 10\% of GDP in 2004, the country is growing fast and it is bumping against all kinds of infrastructure constraints. Should the country slash its deficit, which could hardly be done without affecting public investment, or should it allow the debt to rise while trying to make sure that the social and fiscal returns of those investments exceed the cost of borrowing? It is not an easy decision and we should not pretend it is.

Another area where there may be harder trade-offs than we think, is the issue of the level and stability of the real exchange rate. Under a conventional inflation-targeting regime, the exchange rate is an outcome, not an intermediate instrument. The central bank focuses on keeping expected inflation on target and moves the interest rate to achieve this. The exchange rate will be whatever emerges from that process; it is not a policy instrument. Now, there may be important externalities associated with the level of the real exchange rate that are very important for long-run growth. For example, there may be a trade-off 
between the role that the exchange rate plays de facto in an inflation-targeting regime disciplining the peccadilloes that create inflationary pressures by appreciating the exchange rate and thus lowering the price received by the tradable sector - and the role it plays in stimulating the private sector to remain committed to exports.

Let me report on some calculations I did to explore this issue. Consider the PPP deflator, i.e. ratio of GDP at PPP prices to GDP at market prices. This can be considered an absolute measure of the real exchange rate. We know that, because of the Balassa-Samuelson effect, it tends to fall (i.e. appreciate) with income. I run a regression between this definition of the real exchange rate and the level of development. The residual of this equation can be interpreted as the degree of undervaluation of a currency, controlling for its level of development. By construction on average the residual is zero. Figure 6 shows the rate of growth of GDP per worker of the fastest economies in the past 15 years (the bars) and the rate of undervaluation of the real exchange rate (the line). All the fast growers had undervalued real exchange rates and the growth star - China - is dramatically undervalued by this measure. So there may be a relationship between long-run growth and the real exchange rate. Pure inflation targeting would disregard this connection and hence may create a trade-off between the macro strategy and the growth strategy.

Figure 6. GDP per worker growth vs. currency undervaluation

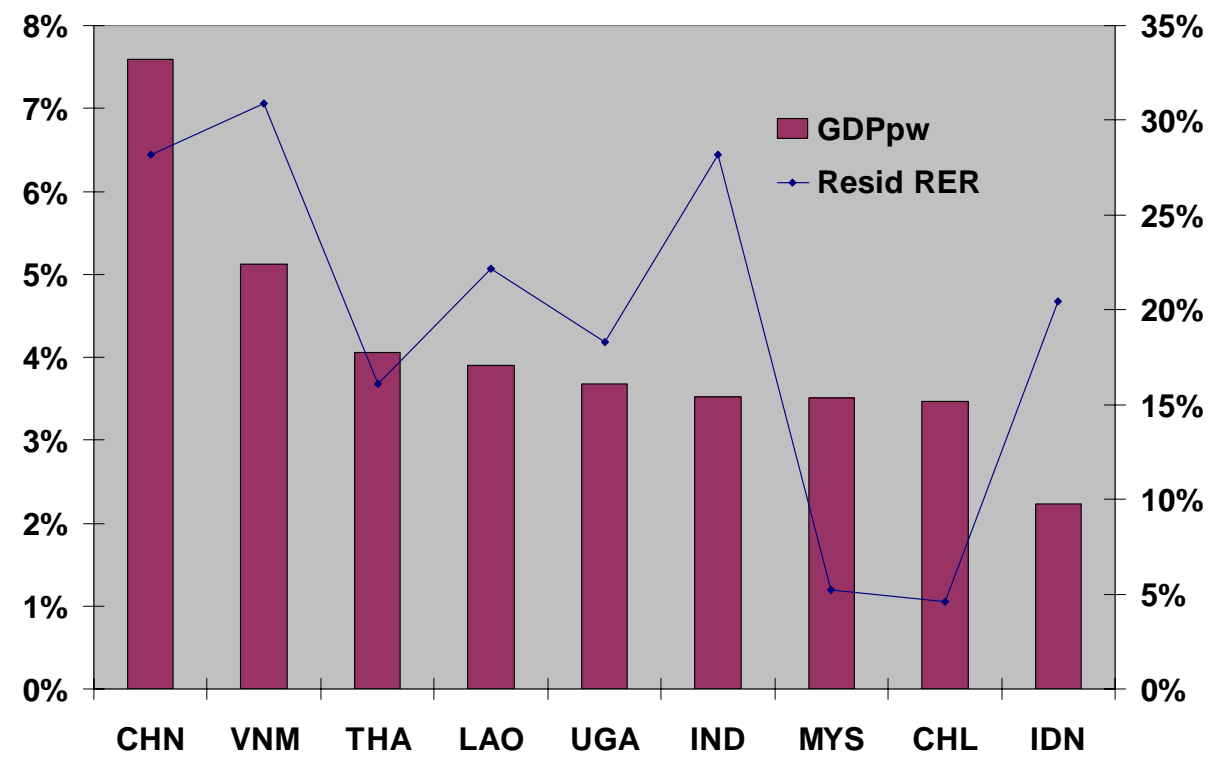

It is important to note that, in contrast with the nominal exchange rate - a weak real exchange rate - defined as the relative price of tradables to non-tradables - can be achieved by all countries. It does not mean that if a country has a high price of tradables to nontradables at home another country must have a low price. Hence, the argument that this is not a strategy that most developing countries can follow is just not true. 


\section{Laissez-faire revisited}

As quoted above, Summers (2003) and Roll and Talbott (2001) implicitly argue that growth is the outcome of well-functioning general market rules. Focus on those and growth will happen. I would like to argue instead that growth involves dealing with many externalities, so that it is not enough just to let the markets do their work. Markets face very significant externalities that impede growth. These externalities come in different flavours.

One form the externalities take is coordination failure. Imagine two complementary investments that could be made in vertically related activities. For example, consider an airport and a hotel in a tourist resort. Unless both investments are made, neither will be profitable: tourists need both a hotel and an airport. The market has no way of coordinating these two investments.

Labour training is another important source of externalities. Investors are always looking for places where there is a well-trained labour force, ideally with experience in their area of activity. And those were trained by somebody else. You can see that any firm will be reluctant to provide the efficient amount of labour training for fear that, since workers can switch jobs, they may not recoup the incurred costs.

There are also very significant information externalities. In order to find out what can be produced in your country, you have to try out many things. But when you finally succeed in identifying a suitable product, people will imitate you. In other words, your efforts provide useful information to other people and you don't get compensated for that. For this reason, the market will under-invest in this search process, limiting investment and entrepreneurship.

These externalities are particularly serious for new activities where their identification suffers from information externalities and at the same time complementary investments have yet to be made and the required labour training done.

In a recent paper with Jason Hwang and Dani Rodrik, we created a measure of the degree of sophistication of a country's export basket and found that it is highly predictive of future growth. In some sense, the level of development of a country tends to converge towards the level of sophistication of its exports. Countries whose exports are very sophisticated for their level of development tend to grow faster. The model would explain the high growth in China and India as a consequence of the fact that their exports are unusually sophisticated exports for a country at their level of income. Hence, market failures in the process of identifying more sophisticated viable exports can have large effects on growth.

When does the process of identifying new products - self-discovery - become the binding constraint in your economy? This will tend to be the case in countries that have already done many of the standard Washington Consensus, so that the most glaring traditional obstacles to economic activity have been removed, the traditional exports face headwinds so that the old things the economy new how to produce are no longer growth poles, and the new activities the economy needs to discover have yet to be identified. 


\section{WHAT REFORM AGENDA EMERGES FROM THIS?}

I would argue that the right reform agenda is highly specific to each context. As Dani Rodrik points out, even if you can specify what you want to achieve with each reform, there are many institutional forms that achieve a given function. I would add that the same reasons that make it hard to repair a plane in mid-flight, make it difficult to attempt institutional solutions that disregard the structures and norms bequeathed by history. Therefore, the idea is not to come up with 10 new points to substitute for John Williamson's ten-point Washington Consensus. We don't need boilerplate solutions, we need better diagnostic tools and a better understanding of how to fix what needs to be fixed efficiently, given a country's inherited institutions and practices.

So the agenda for growth should not attempt to define a new set of recipes. This does not mean that we cannot agree on a set of shared goals. For example, we may quickly arrive at a list of goals such as successful integration to the global economy, sound money and public finances, effective protection of property rights and dynamic innovation. The problem is that achieving these goals does not map clearly into a single set of institutions and policies.

In this respect, I believe that the concept of best practice has been counter-productive and often quite dangerous. Suppose you are in a country in which the political system has been quite unstable, the macroeconomy has been stabilised and structural reforms have been implemented but the market is unsure of their sustainability. The court system lacks independence and credibility. Should the country focus on political and judicial reform in order to allay investor fears? Should it try to incorporate some of the main structural reform measures into the constitution in order to make them harder to change, as Argentina did with the currency board in the early 1990s? Or should it find ad hoc solutions that may give sufficient security to potential investors so that the existing institutional failures become less relevant?

I call this last strategy the scaffolding approach. When you look at a bridge, you realise that it holds up because all the parts support each other. Precisely for this reason, it is impossible to build the bridge without scaffolding. You cannot put in place at the same time all its parts. Paraphrasing this example, you cannot get the macroeconomic, structural, political, judicial and social underpinnings of an economy all in place before you get the economy going. It is hard to achieve macro stability without growth, as growth generates the tax revenues that make it easier to sustain fiscal discipline. It is impossible to maintain political stability without macro stability and growth. It is very difficult to sustain structural reforms if the body politic does not see any pay-offs.

The "best practice" approach consists of trying to build the bridge with no scaffolding. It looks at the best bridges around and tries to mimic them. Ad hoc solutions are the scaffolding that supports the structure while it is being built. Suppose you have an overprotected economy with a strong anti-export bias and lousy infrastructure. A regime of export-processing zones can provide the right trade regime and infrastructure to a section of the economy and thus permit it to grow. Once it exists and is generating employment, income, a political constituency and a successful example to emulate, it may be easier to try to make the rest of the economy more similar to that successful enclave. Such examples 
abound. If investors distrust the legal regime, it may be possible to structure investments as contracts which can only be changed with the agreement of both sides and to make them subject to international arbitration. If crime is preventing a tourism industry from developing, it is easier to provide security in a limited part of the country than it is to do it across the board. Once the tourism industry is booming, you may have the resources and the political conditions to extend security to the rest of the country. In fact, permanent solutions often are adopted as generalisations of successful ad hoc solutions. This explains in part the enormous diversity of institutional solutions across industrial countries.

Another big question is the "who" of the reform process. If we think dynamically, a society needs to identify externalities and market failures, address them while containing government failures (capture, corruption, moral hazard) and weaning out the solutions that are ineffective. Who is going to do this? What is the institutional process whereby this will take place over time?

Whatever it is, it involves cooperation between the government and society at large, especially the private sector, in order to identify the opportunities and obstacles. It requires policy experimentation and generalisation once these policy experiments are successful. So it is not about copying the best practices and hoping for the best. It is about trying things out, seeing if they work, and then scaling them up. I suggest that this is the most important challenge when thinking about institutional design and policy reform.

\section{IN SYNTHESIS...}

There is more to growth than good macro policy. You will have wasted your time if you got here to say: "Well, we know that growth is very important and therefore we will concentrate on fiscal consolidation and low inflation and that is our contribution to the growth strategy." That is not enough; I think it is more complicated. However, not too complicated either.

Growth accelerations do not require a large set of deep reforms, but a more effective focus on identifying and removing the binding constraints to growth. Growth involves coping not only with government failures, so it is not just about eliminating existing government failures, but also about eliminating market failures and these require government action. So, it is not just sins of commission that drive down growth, it is also sins of omission, things that governments are not doing to overcome market failures. In many instances, there are ad hoc solutions that get the job done without having to wait for long-term solutions to be credibly put in place. Such action requires an institutional setting that allows for a dynamic policy process where problems are identified and addressed, while containing government failure.

That was what I had planned to say, and I have now said it, so thank you very much. 


\section{REFERENCES:}

Krueger, A (2004) Meant well, tried little, failed much: policy reforms in emerging economies. Roundtable Lecture, Economic Honors Society, New York University, http://www.imf.org/external/np/speeches/2004/032304a.htm

Hausmann, R, Hwang, J and Rodrik, D (2005) What you export matters, NBER Working Paper No. 11905.

Hausmann, R, Pritchett, L and Rodrik, D (2006) Growth accelerations, Journal of Economic Growth (forthcoming)

Hausmann, R, Rodrik, D and Velasco, A (2005) Growth diagnostics, Journal of Economic Growth.

Perotti, R (1996) American Economic Review, 86(2), Papers and Proceedings of the 108th Annual Meeting of the American Economic Association, San Francisco, CA, January 5-7, 1996 (May, 1996), pp. 105-110

Rodrik, D (2006) Growth strategies, in Aghion, P and Durlauf, S (eds), Handbook of economic growth, North-Holland

Summers, LH (2003) Godkin Lectures, mimeo Harvard University. 


\section{Appendix}

The fastest-growing countries: 1988-2003 (15 years)

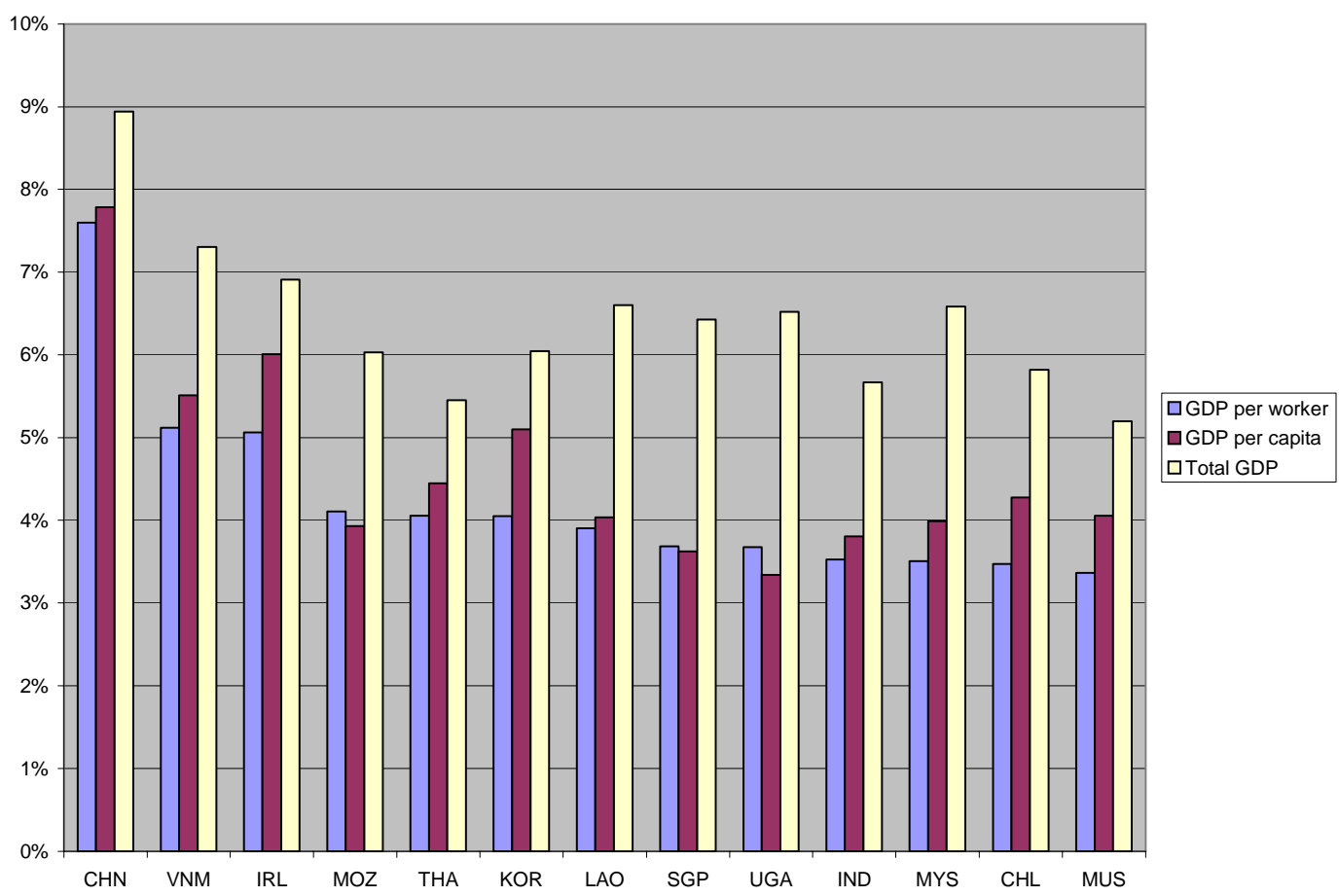

Fastest-growing countries in any 15-year period since 1960

\begin{tabular}{lrrrrr}
\hline Country & \multicolumn{1}{c}{$\begin{array}{l}\text { End } \\
\text { year }\end{array}$} & Population & $\begin{array}{c}\text { GDP } \\
\text { per worker }\end{array}$ & \multicolumn{1}{c}{$\begin{array}{l}\text { Total } \\
\text { GDP }\end{array}$} & $\begin{array}{c}\text { GDP } \\
\text { per capita }\end{array}$ \\
\hline BWA & 1983 & 1.0 & $11.0 \%$ & $14.5 \%$ & $10.5 \%$ \\
CHN & 1997 & 1230.0 & $8.5 \%$ & $10.5 \%$ & $9.0 \%$ \\
JPN & 1975 & 112.0 & $6.8 \%$ & $8.4 \%$ & $7.2 \%$ \\
GRC & 1975 & 9.0 & $6.5 \%$ & $6.8 \%$ & $6.2 \%$ \\
SGP & 1979 & 2.4 & $6.3 \%$ & $10.3 \%$ & $8.4 \%$ \\
KOR & 1996 & 45.5 & $6.1 \%$ & $8.5 \%$ & $7.3 \%$ \\
THA & 1996 & 59.0 & $5.9 \%$ & $8.1 \%$ & $6.6 \%$ \\
SYR & 1981 & 9.0 & $5.8 \%$ & $9.0 \%$ & $5.4 \%$ \\
ESP & 1975 & 35.5 & $5.8 \%$ & $6.7 \%$ & $5.6 \%$ \\
DZA & 1977 & 17.0 & $5.8 \%$ & $7.8 \%$ & $4.8 \%$ \\
LSO & 1978 & 1.2 & $5.7 \%$ & $7.4 \%$ & $5.3 \%$ \\
HUN & 1975 & 10.5 & $5.6 \%$ & $6.3 \%$ & $5.9 \%$ \\
HKG & 1990 & 5.7 & $5.5 \%$ & $8.2 \%$ & $6.3 \%$ \\
CMR & 1986 & 10.4 & $5.4 \%$ & $7.7 \%$ & $4.7 \%$ \\
COG & 1982 & 1.9 & $5.3 \%$ & $8.3 \%$ & $5.1 \%$ \\
IRL & 2002 & 3.9 & $5.3 \%$ & $7.0 \%$ & $6.3 \%$ \\
VNM & 2003 & 81.3 & $5.1 \%$ & $7.3 \%$ & $5.5 \%$ \\
IDN & 1981 & 151.0 & $4.9 \%$ & $7.7 \%$ & $5.2 \%$ \\
PRT & 1975 & 9.1 & $4.8 \%$ & $5.7 \%$ & $5.6 \%$ \\
CHL & 1998 & 14.8 & $4.8 \%$ & $7.4 \%$ & $5.7 \%$ \\
BRA & 1980 & 122.0 & $4.8 \%$ & $8.2 \%$ & $5.6 \%$ \\
& & & & &
\end{tabular}


Fastest-growing countries in any 25-year period since 1960

\begin{tabular}{|c|c|c|c|c|c|}
\hline Country & $\begin{array}{l}\text { End } \\
\text { year }\end{array}$ & Population & $\begin{array}{c}\text { GDP } \\
\text { per worker }\end{array}$ & $\begin{array}{c}\text { GDP } \\
\text { per capita }\end{array}$ & $\begin{array}{l}\text { Total } \\
\text { GDP }\end{array}$ \\
\hline BWA & 1989 & 1.2 & $9.4 \%$ & $8.8 \%$ & $12.5 \%$ \\
\hline OMN & 1986 & 1.4 & $8.7 \%$ & $8.7 \%$ & $12.8 \%$ \\
\hline CHN & 2002 & 1280.0 & $7.7 \%$ & $8.1 \%$ & $9.5 \%$ \\
\hline KOR & 1990 & 42.9 & $5.6 \%$ & $6.7 \%$ & $8.5 \%$ \\
\hline SGP & 1989 & 2.9 & $5.4 \%$ & $7.1 \%$ & $9.1 \%$ \\
\hline HKG & 1988 & 5.6 & $5.3 \%$ & $6.3 \%$ & $8.4 \%$ \\
\hline JPN & 1985 & 121.0 & $5.2 \%$ & $5.5 \%$ & $6.5 \%$ \\
\hline THA & 1996 & 59.0 & $4.9 \%$ & $5.6 \%$ & $7.7 \%$ \\
\hline LSO & 1996 & 1.7 & $4.8 \%$ & $4.6 \%$ & $6.6 \%$ \\
\hline HUN & 1985 & 10.6 & $4.7 \%$ & $4.6 \%$ & $4.8 \%$ \\
\hline IDN & 1992 & 184.0 & $4.6 \%$ & $5.2 \%$ & $7.4 \%$ \\
\hline GRC & 1985 & 9.9 & $4.2 \%$ & $4.1 \%$ & $4.9 \%$ \\
\hline IRL & 2001 & 3.9 & $4.2 \%$ & $4.7 \%$ & $5.5 \%$ \\
\hline MYS & 1996 & 21.1 & $4.1 \%$ & $4.9 \%$ & $7.6 \%$ \\
\hline EGY & 1985 & 46.5 & $3.8 \%$ & $3.7 \%$ & $6.1 \%$ \\
\hline SYR & 1985 & 10.4 & $3.7 \%$ & $3.2 \%$ & $6.6 \%$ \\
\hline ESP & 1985 & 38.4 & $3.7 \%$ & $3.7 \%$ & $4.7 \%$ \\
\hline LVA & 1990 & 2.7 & $3.6 \%$ & $3.7 \%$ & $4.4 \%$ \\
\hline DZA & 1987 & 23.2 & $3.6 \%$ & $3.3 \%$ & $6.3 \%$ \\
\hline AUT & 1985 & 7.6 & $3.6 \%$ & $3.3 \%$ & $3.6 \%$ \\
\hline ITA & 1985 & 56.6 & $3.5 \%$ & $3.6 \%$ & $4.1 \%$ \\
\hline
\end{tabular}

